\title{
Determination of pyrimidine 5'-nucleotidase (P5N) activity in whole blood as an index of lead exposure
}

\author{
T SAKAI, T ARAKI, K USHIO \\ From the Center of Occupational Medicine, Tokyo Labor Accident Hospital, Ota-Ku, Tokyo 143, Japan
}

\begin{abstract}
A simple method for determining pyrimidine 5'-nucleotidase (P5N) activity in whole blood has been developed, inhibiting the plasma activity for UMP-hydrolysis by concanavalin (Con A). Con A specifically inhibits the activity of plasma 5'-nucleotidase (5N) but does not affect erythrocyte P5N activity. The anticoagulant EDTA partially inhibits $5 \mathrm{~N}$ activity but slightly activates P5N. P5N activity determined by the present method with heparinised blood and Con A was comparable with that by the method reported previously and correlated well with blood lead concentrations. The mean value and SD for P5N activity in normal subjects $(n=72)$ not exposed to lead are 16.2 and $2.5 \mu \mathrm{mole} / \mathrm{h} / \mathrm{g} \mathrm{Hb}$, respectively. The present method can eliminate not only the isolation step of $\mathrm{RBC}$ but also $\mathrm{Hb}$ determination, the activity being expressed as $\mu \mathrm{mole} / \mathrm{h} / \mathrm{l}$ blood or $\mathrm{RBC}$. Thus the procedures are so simplified that the assay may be used as a routine test for mass screening of lead exposure.
\end{abstract}

Pyrimidine 5'-nucleotidase (P5N, EC 3.1.3.5) in the red cell cytosol catalyses the hydrolytic dephosphorylation of pyrimidine $5^{\prime}$-monophosphates but is ineffective on purine nucleotidase. The presence of P5N was first reported by Valentine et al in 1974 in their description of haemolytic anaemia.' Hereditary P5N deficiency results in a non-spherocytic haemolytic anaemia in which the erythrocytes contain extremely high concentrations of pyrimidine nucleotides and show pronounced basophilic stippling. Erythrocyte P5N activity is also known to decline in lead poisoning. ${ }^{2-4}$ The measurement of the enzyme activity has a diagnostic value in these disorders.

The conventional method for determining P5N activity is based on the liberation of inorganic phosphorus from pyrimidine 5 -nucleotides and requires time consuming and complicated procedures, limiting its application in the clinical laboratory. We have previously developed a rapid and sensitive method for $\mathrm{P} 5 \mathrm{~N},{ }^{5-6}$ in which the product (uridine) is separated from the substrate (UMP) and red cell constituents by means of high performance liquid chromatography (HPLC). Because the amount of endogenous uridine is non-detectable and the intensity of the absorption of uridine is high at $254 \mathrm{~nm}$, the need to dialyse the sample is eliminated and the incubation time is

Accepted 6 April 1987 shortened. Nevertheless, the method still requires washed erythrocytes as the enzyme source, since serum 5 '-nucleotidase $(5 \mathrm{~N})$ non-specifically hydrolyses 5 '-nucleotide to release inorganic phosphate at neutral condition. $5 \mathrm{~N}$ activity is known to be increased in hepatobiliary disease and serves as a diagnostic tool for the disorder. ${ }^{7-8}$ In the present paper we describe $\mathrm{P} 5 \mathrm{~N}$ assay in whole blood, inhibiting $5 \mathrm{~N}$ activity by a specific inhibitor, concanavalin A (Con A). ${ }^{910}$

\section{Materials and methods}

Venous blood, treated with EDTA-2K or heparin as anticoagulants, was obtained from lead workers and from normal subjects with no history of exposure to lead. The lead workers were employed in secondary smelters, glass factories, and printing offices. Erythrocytes were separated from plasma, washed twice with a 10 -fold volume of saline $(0.9 \% \mathrm{NaCl})$, and then suspended in saline (about 50\% suspension; $\mathrm{RBC} /$ saline). For the determination of $\mathrm{P} 5 \mathrm{~N}$ or $5 \mathrm{~N}$ activity whole blood, or both, $\mathrm{RBC} /$ saline or plasma were used for the enzyme sources. P5N (and/or 5N) activity was determined by the method previously reported with some modifications ${ }^{56}$ as follows: the enzyme solution was prepared by diluting $50 \mu \mathrm{l}$ of blood, $\mathrm{RBC} /$ saline, or plasma to $550 \mu \mathrm{l}$ with distilled water. Commercially available UMP-Na (Sigma Chemical Co, Saint Louis, USA) was used as the substrate without purification 
instead of buffered substrate as in the original method. ${ }^{5}$ The standard assay mixture contained $550 \mu$ of enzyme solution, $100 \mu \mathrm{l}$ of $0.2 \mathrm{M}$ Tris- $\mathrm{HCl}$ buffer $(\mathrm{pH}$ 7.7) containing $75 \mathrm{mM} \mathrm{MgCl}_{2}, 50 \mu \mathrm{l}$ of Con A (type IV, Sigma Chemical Co, Saint Louis, USA) solution $(20 \mathrm{~g} /$ 1), and $50 \mu \mathrm{l}$ of $50 \mathrm{mM}$ UMP-Na. To determine the P5N activity without Con $\mathrm{A}$, distilled water was added to the mixture instead of Con A solution. The reaction was started by adding substrate at $37^{\circ} \mathrm{C}$. After 60 minutes the reaction was terminated by placing the tubes in boiling water for three minutes. Then $2.25 \mathrm{ml}$ of distilled water were added to the mixture and agitated. After centrifugation, the resulting supernatant was used for the HPLC analysis. A Shimadzu liquid chromatograph (Shimadzu, Kyoto, Japan) consisting of a pump (LC-3A), an automatic sample injector (SIL-2A), a column oven (CTO-2A), a variable wavelength spectrophotometer (SPD-1), and an integrator (C-R1A) was used. Flow rate, oven temperature, and detector wavelength were set at $1.0 \mathrm{ml} /$ min, $40^{\circ} \mathrm{C}$, and $254 \mathrm{~nm}$, respectively. The column $(150 \times 4 \mathrm{~mm})$ used was packed with reversed phase (ODS) silica. The mobile phase was $5 \%$ methanol containing $5 \mathrm{mM} \mathrm{KH}_{2} \mathrm{PO}_{4}$ and $0.2 \mathrm{mM}$ 1-decanesulphonic acid. Samples were cooled at $4^{\circ} \mathrm{C}$ during a series of analyses and $10 \mu \mathrm{l}$ were automatically injected at seven minute intervals. The unit (u) of P5N activity was expressed as $\mu$ mole $/ \mathrm{h} / \mathrm{g} \mathrm{Hb}, \mu$ mole $/ \mathrm{h} / \mathrm{l} \mathrm{RBC}$, or $\mu \mathrm{mole} / \mathrm{h} / \mathrm{l} \mathrm{blood}$, and that of plasma $5 \mathrm{~N}$ as $\mu \mathrm{mole} / \mathrm{min} / \mathrm{l}$. Serum $5 \mathrm{~N}$ activity $(\mu \mathrm{mole} / \mathrm{min} / \mathrm{l})$ in some subjects was also determined by the method of Belfield et al. ${ }^{11} \mathrm{Hb}$ concentrations in $\mathrm{RBC} /$ saline or blood were determined using a haemoglobin counter (TOA Medical Electronic Co, Tokyo, Japan), which directly measured $\mathrm{Hb}$ concentrations spectrophotometrically as cyanmethaemoglobin. Blood lead concentrations $(\mathrm{Pb}-\mathrm{B})$ were determined by the method previously reported. ${ }^{12}$

\section{Results}

Figure 1 shows the effect of increasing amounts of inhibitor Con A on hydrolysis of UMP by blood from a normal subject whose $5 \mathrm{~N}$ activity in serum was 21.3 $\mu \mathrm{mole} / \mathrm{min} / \mathrm{l}$. Zero to $5 \mathrm{mg}$ of Con A are added to the reaction mixtures to produce final concentrations of 0 to $6.67 \mathrm{mg} / 1$ of Con A. The activity of heparinised blood declines in a linear fashion as the amount of inhibitor increases up to $0.5 \mathrm{mg}$ but no further decline is observed when the amount of the inhibitor exceeds $0.5 \mathrm{mg}$. It appears that the difference between the activity in the presence and absence of Con A corresponds to the action of $5 \mathrm{~N}$ in plasma, and that the residual activity with Con A exceeding $0.5 \mathrm{mg}$ represents the hydrolysis of UMP by erythrocyte

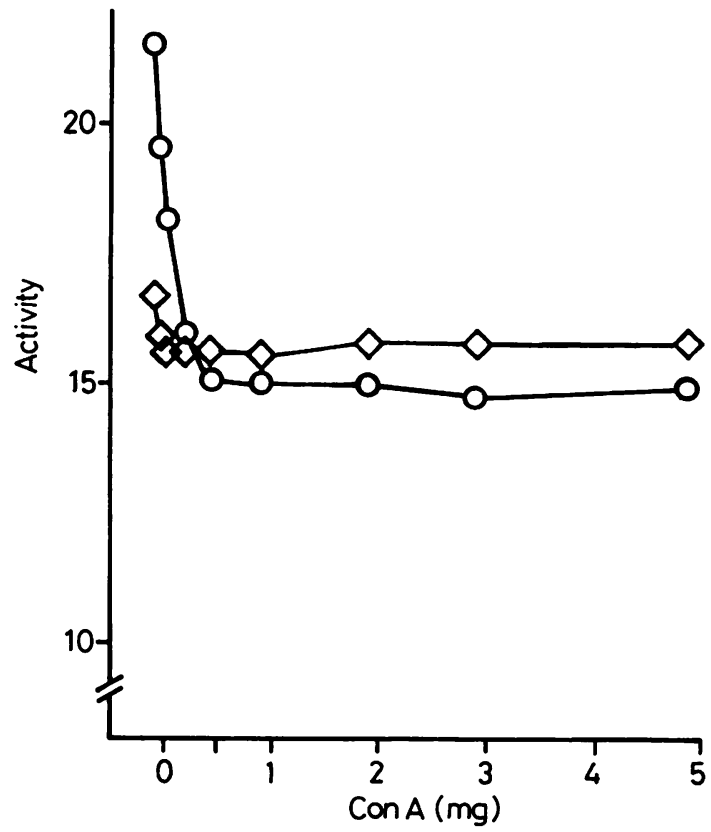

Fig 1 Effect of increasing amounts of Con $A$ on hydrolysis of UMP ( $\mu$ mole $/ \mathrm{h} / \mathrm{g} \mathrm{Hb}$ ) by blood from a normal subject whose $5 N$ activity in serum is $21 \cdot 3 \mu \mathrm{mole} / \mathrm{min} / \mathrm{l}$. Blood treated with EDTA $(\diamond)$ or heparin ( $\bigcirc)$ was used as enzlme sources. Zero to $5 \mathrm{mg}$ of Con $A$ was added to reaction mixture.

enzyme (P5N). The effect of Con A on UMPhydrolysis of blood treated with EDTA differs considerably from that of heparinised blood. Even without addition of Con A, hydrolysis of UMP by blood treated with EDTA is weaker than that by heparinised blood. The activity of EDTA treated blood is further reduced with the addition of Con A. The residual activity, however, is slightly higher than that of heparinised blood. To discover the effects of EDTA or Con A, or both, on the enzymic hydrolysis of UMP by blood, plasma or erythrocytes from heparinised blood were examined separately. Table 1

Table 1 Effect of EDTA or Con A, or both, on the hydrolysis of UMP by plasma

\begin{tabular}{lc}
\hline & Activity $(\mu$ mole/min/l) \\
\hline Control & $10 \cdot 88 \pm 0.139$ \\
+Con A & $1.92 \pm 0.113$ \\
+EDTA & $1.84 \pm 0.106$ \\
+ EDTA + Con A & $1.46 \pm 0.073$ \\
\hline Plasma pooled from heparinised blood was used as the enzyme \\
source with or without treatment of EDTA, which was carried out \\
by incubating plasma with EDTA-2K (8 mM) for 20 hours at $4^{\circ} \mathrm{C}$. \\
Con A (1 mg) was added to the reaction mixture. Results were the \\
mean \pm SD of triplicate determinations.
\end{tabular}


shows the action of EDTA or Con A, or both, on the activity of plasma (5N). The hydrolysis of UMP by plasma from a normal subject is depressed by both Con A and EDTA. The depressed activity is not restored by the addition of $\mathrm{Mg}$ ion to the reaction mixture at concentrations up to $70 \mathrm{mM}$ (data not shown). In erythrocytes treated with EDTA the hydrolysis of UMP is slightly (about $10 \%$ ) augmented, whereas Con A has no effect on the hydrolysis of UMP by erythrocytes (table 2). The augmentation of UMP hydrolysis is reversible, since the activity returns to the control level by rewashing the erythrocytes with saline (table 3).

To confirm further the effects of the anticoagulant and of Con A on the hydrolysis of UMP by whole blood and erythrocytes, we determined the activity in

Table 2 Effect of EDTA or Con A, or both, on the hydrolysis of UMP by $R B C /$ saline

\begin{tabular}{ll}
\hline & Activity $(\mu$ mole $/ \mathbf{h} / \mathrm{g} \mathrm{Hb})$ \\
\hline Control & $13 \cdot 7 \pm 0 \cdot 28$ \\
+ Con A & $13 \cdot 6 \pm 0 \cdot 26$ \\
+ EDTA & $15 \cdot 1 \pm 0 \cdot 21$ \\
+ EDTA + Con A & $15 \cdot 0 \pm 0.25$ \\
\hline
\end{tabular}

$\mathrm{RBC} /$ saline from normal heparinised blood was used as the enzyme source with or without treatment of EDTA, which was carried out by incubating RBC/saline with EDTA-2K $(8 \mathrm{mM})$ for 20 hours at $4^{\circ} \mathrm{C}$ Con $A(1 \mathrm{mg})$ was added to the reaction mixture. Results were the mean $\pm S D$ of triplicate determinations.

Table 3 Reversible effect of EDTA treatment on the hydrolysis of UMP by RBC/saline from a normal subject and a lead worker

\begin{tabular}{lll}
\hline & \multicolumn{2}{l}{ Activity $(\mu$ mole $/ \mathrm{h} / \mathrm{g} H \mathrm{~b})$} \\
\cline { 2 - 3 } & Normal subject & Lead worker \\
\hline Control & $15 \cdot 6 \pm 0.41$ & $4.6 \pm 0.09$ \\
EDTA treatment & $16.1 \pm 0.07$ & $5.9 \pm 0.11$ \\
Rewashing & $15.2 \pm 0.10$ & $4.6 \pm 0.09$ \\
\hline
\end{tabular}

$\mathrm{RBC} /$ saline was treated with EDTA as described in table 2 (EDTA treatment) and then rewashed with saline (rewashing). The results were the mean \pm SD of triplicate determinations. samples from 16 lead workers (mean $\mathrm{Pb}-\mathrm{B} \pm \mathrm{SD}$, $12.4 \pm 3.7 \mu \mathrm{g} / 100 \mathrm{~g})$ under various conditions as shown in table 4 . With the exception of activities in whole blood without Con A (WH-, WE-), the data obtained are comparable with those of the method reported earlier ${ }^{6}$ in which erythrocytes from heparinised blood $\left(\mathrm{RH}^{-}\right)$are used as enzyme source. Data

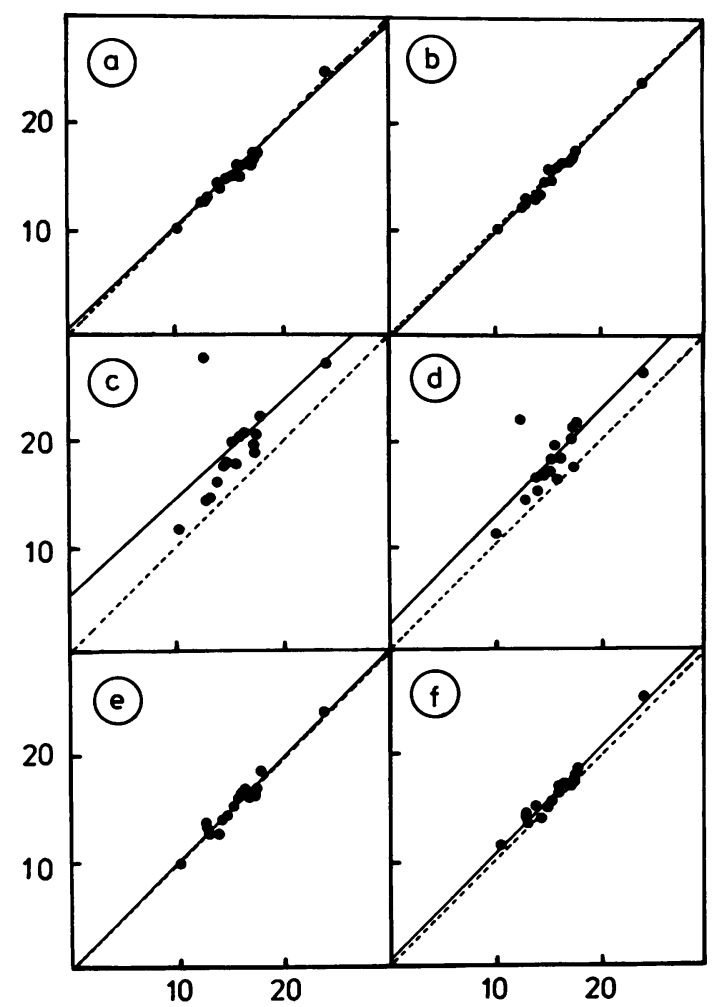

Fig 2 Relations between P5N activity ( $y$ ) by various methods as in table 4 and that with heparinised $R B C$ without inhibitor ( $x, R H-)$. Correlation coefficients and regression equations are also shown in table 4. Both regression (-) and identical (_ - - ) lines are shown.

Table 4 Various methods for P5N assay and comparison of data (y) with those ( $x)$ using the method (RH-) reported $(5-6)$ in 16 lead workers

\begin{tabular}{|c|c|c|c|c|c|c|c|c|c|c|}
\hline \multirow[b]{2}{*}{ Method } & \multirow{2}{*}{$\begin{array}{l}\text { Enzyme } \\
\text { source }\end{array}$} & \multirow{2}{*}{$\begin{array}{l}\text { Anti- } \\
\text { coagulant }\end{array}$} & \multirow[b]{2}{*}{$\operatorname{Con} A$} & \multicolumn{2}{|c|}{ Activity ( $\mu$ mole $/ \mathrm{h} / \mathrm{g} H b)$} & \multirow{2}{*}{$\begin{array}{l}\text { Level of } \\
\text { significance }\end{array}$} & \multicolumn{3}{|c|}{ Linear regression analysis } & \multirow[b]{2}{*}{ Fig 2} \\
\hline & & & & Mean & $S D$ & & Slope & $y$-intercept & $r$ & \\
\hline $\begin{array}{l}\text { WH + } \\
\text { WH - } \\
\text { WE + } \\
\text { WE- } \\
\text { RH + } \\
\text { RH - } \\
\text { RE+ } \\
\text { RE - }\end{array}$ & $\begin{array}{l}\mathbf{W} \\
\mathbf{W} \\
\mathbf{W} \\
\mathbf{W} \\
\mathbf{R} \\
\mathbf{R} \\
\mathbf{R} \\
\mathbf{R}\end{array}$ & $\begin{array}{l}\mathbf{H} \\
\mathbf{H} \\
\mathbf{E} \\
\mathbf{E} \\
\mathbf{H} \\
\mathbf{H} \\
\mathbf{E} \\
\mathbf{E}\end{array}$ & $\begin{array}{l}+ \\
\bar{t} \\
\overline{+} \\
\bar{t} \\
+ \\
-\end{array}$ & $\begin{array}{l}15 \cdot 46 \\
19 \cdot 66 \\
16 \cdot 39 \\
18 \cdot 33 \\
15 \cdot 23 \\
15 \cdot 46 \\
15 \cdot 52 \\
15 \cdot 37\end{array}$ & $\begin{array}{l}2.99 \\
4.35 \\
3.07 \\
3.81 \\
3.01 \\
2.99 \\
2.95 \\
2.95\end{array}$ & $\begin{array}{l}\text { NS } \\
p_{\mathrm{NS}}<0.01 \\
\mathrm{p}_{\mathrm{NS}}<0.05\end{array}$ & $\begin{array}{l}1.009 \\
0.923 \\
1.011 \\
1.003 \\
1.002\end{array}$ & $\begin{array}{l}0.0735 \\
5.38 \\
0.752 \\
2.439 \\
-0.259 \\
\\
0.666 \\
0.295\end{array}$ & $\begin{array}{l}0.97 \\
0.63 \\
0.98 \\
0.81 \\
0.99\end{array}$ & $\begin{array}{l}\text { (e) } \\
\text { (c) } \\
\text { (f) } \\
\text { (d) } \\
\text { (b) }\end{array}$ \\
\hline
\end{tabular}

$\mathrm{W}=$ Whole blood, $\mathrm{R}=\mathrm{RBC} /$ saline, $\mathrm{H}=$ heparin, $\mathrm{E}=\mathrm{EDTA}, \mathrm{NS}$ : Not significant. 
obtained by the various methods in table 4 correlate well with those of the method reported previously (fig 2 ). Figure $2 a$ shows that the data with $R B C$ from EDTA treated blood (RE - ) are similar to those of the method $(\mathrm{RH}-)$ reported previously, indicating that the activating effect of EDTA on the erythrocyte enzyme is eliminated by washing erythrocytes with saline. It is also confirmed that Con A has no effect on the erythrocyte enzyme (fig 2b). The activities obtained with blood treated with EDTA (WE-)or heparin $(\mathrm{WH}-)$ are higher $(27.2 \%$ or $21.8 \%$, respectively) than those using the previous method ( $\mathrm{RH}-$, figs $2 c$ and d). It appears that the differences between activity with whole blood and with erythrocytes are due mainly to the plasma action $(5 \mathrm{~N})$ of hydrolysis. The amount of EDTA used as anticoagulant seems to be not sufficient totally to inhibit the activity of plasma (fig 2d). The concentration should not be so high as in the experiments reported in table 1 . Activities determined with heparinised blood and Con A (WH+) agree well with those of the earlier method $(\mathrm{RH}-$, fig 2e), whereas data from EDTA treated blood and Con A (WE +) are slightly higher ( $\mathrm{RH}-$, fig $2 \mathrm{f})$. The slightly raised activity in EDTA treated blood (WE +) is due to the weak activation of erythrocyte enzyme by EDTA. Based on these findings, it appears that Con A is useful as a differential inhibitor of enzymic hydrolysis of UMP by plasma $5 \mathrm{~N}$ and erythrocyte P5N.

To evaluate the method for determining P5N activity with whole blood and Con $A$, we adopted it to the larger group of lead workers $(n=37)$. Figure 3 shows the relations between $\mathrm{Pb}-\mathrm{B}$ and $\mathrm{P} 5 \mathrm{~N}$ activity determined with whole blood in the presence or absence of Con A. When P5N activity is determined with whole blood in the presence of Con A (figs 3a, c), correlation coefficients of $\mathrm{Pb}-\mathrm{B} v \log \mathrm{P} 5 \mathrm{~N}$ are improved by comparison with those in the absence of inhibitor (figs $3 b, d$ ). In the presence of Con $A$ the activities with EDTA treated blood (fig 3c) are slightly higher (about 10\%) than those with heparinised blood (fig 3a). Thus in the present study the method with heparinised blood and Con $\mathrm{A}(\mathrm{WH}+)$ was selected for determining P5N activity in lead workers. The activity may be expressed in $\mu$ mole/ $/ \mathrm{h} / \mathrm{l}$ blood or $\mathrm{RBC}$, omitting the measurement of $\mathrm{Hb}$. In the expression of $\mu \mathrm{mole} / \mathrm{h} / \mathrm{l}$ RBC, however, Hct determination is necessary. In 83 lead workers we compared the expression of the three types of unit with regard to the relation of Pb-B $v$ P5N activity (fig 4). A strong negative correlation was observed between $\mathrm{Pb}-\mathrm{B}$ and $\log \mathrm{P} 5 \mathrm{~N}$ activity expressed in $\mu \mathrm{mole} / \mathrm{h} / \mathrm{l} \mathrm{RBC}(\mathrm{r}=-0.91)$ and in $\mu \mathrm{mole} / \mathrm{h} / \mathrm{l}$ blood $(r=-0.88)$ and when expressed in conventional units $(r=-0.91)$. The three units may be converted using the equations given in table 5 .

In the present method with heparinised blood and

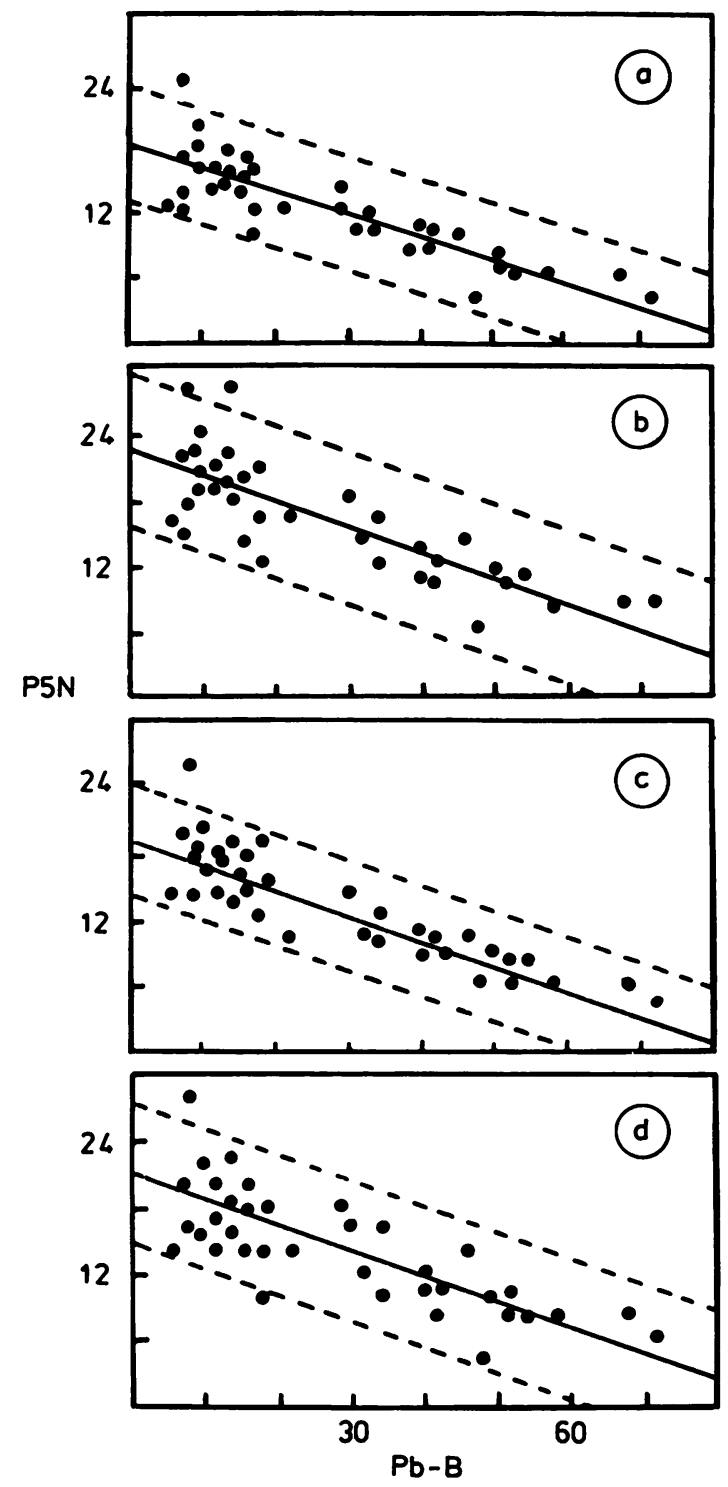

Fig 3 Relations between $\mathrm{Pb}-\mathrm{B}(\mu \mathrm{g} / 100 \mathrm{~g})$ and $\mathrm{P} 5 \mathrm{~N}$ activity ( $\mu \mathrm{mole} / \mathrm{h} / \mathrm{g} \mathrm{Hb}$ ) in blood from 37 lead workers. P5N activity was determined by four types of method in table 4. Regression lines (-) and $95 \%$ predictive interval of individual values (- - - ) are shown in figures. (a) $\mathrm{WH}+$,

$y=-0.212 x+18.22(r=-0.85)$ or $\log$

$y=-0.00887 x+1.303(r=-0.89)$, (b) WH-,

$y=-0.236 x+22.37(r=-0.80)$ or $\log$

$y=-0.00721 \times+1.373(r=-0.85)$, (c) $W E+$,

$y=-0.227 \times+18.97(r=0.87)$ or $\log$

$y=-0.00927 x+1.33(r=-0.92),(d) W E-$,

$y=-0.235 x+21 \cdot 15(r=0.83)$ or $\log$

$y=0.00801 \times+1.36(r=-0.86)$. 
Con A the reference value was determined in a control group of non-exposed men $(n=72)$. The arithmetic mean and SD of P5N activity were 16.2 and $2.5 \mu \mathrm{mole} /$ $\mathrm{h} / \mathrm{g} \mathrm{Hb}$, respectively. The age of the subjects ranged between 19 and 55 (mean $\pm \mathrm{SD}, 34.4 \pm 6.0$ ). No significant relation was found between age $(x)$ and P5N activity (y) $(\mathrm{y}=0.0192 \mathrm{x}+15.5, \mathrm{r}=0.09)$. Within assay and between assay CVs are shown in table 6 , indicating that the precision of the present method is sufficiently accurate to detect decreased activity in subjects exposed to lead.

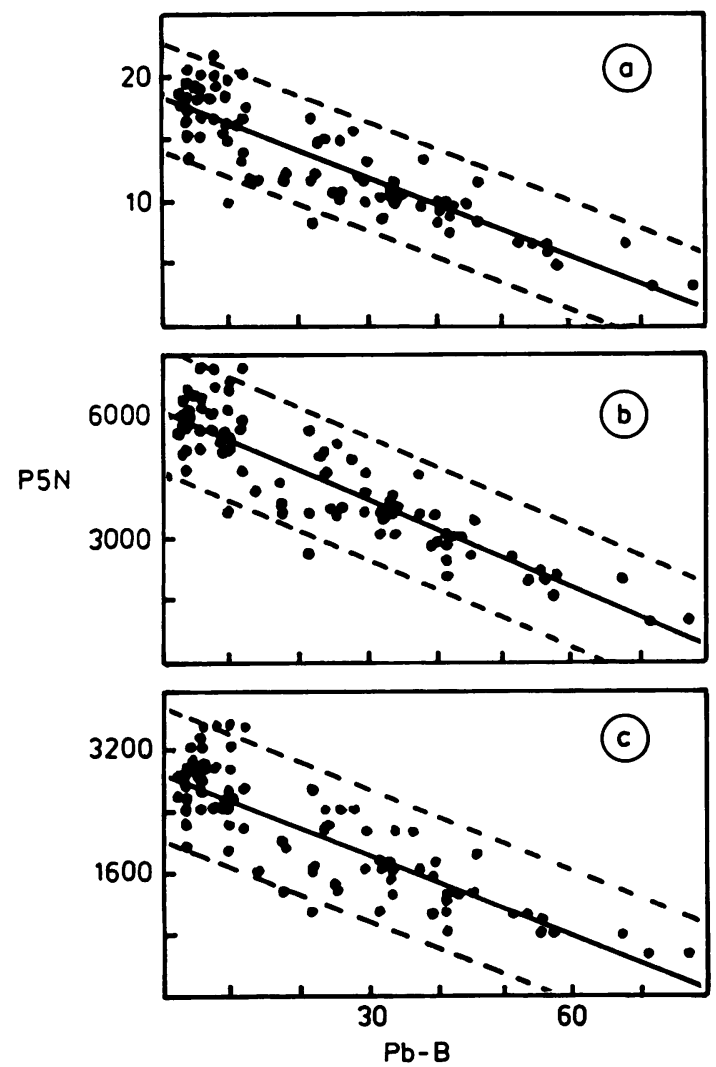

Fig 4 Relations between $\mathrm{Pb}-\mathrm{B}(\mu \mathrm{g} / 100 \mathrm{~g})$ and $\mathrm{P} 5 \mathrm{~N}$ activity expressed in three types of unit by method " $W H+$ " in 83 lead workers. P5N activity was corrected with $\mathrm{Hb}(a, \mu$ mole) $\mathrm{h} / \mathrm{g} \mathrm{Hb}$ ) or with $\mathrm{Hct}(\mathrm{b}, \mu \mathrm{mole} / \mathrm{h} / \mathrm{l} \mathrm{RBC})$, or not corrected (c, , mole/h/l blood). Regression lines (-) and $95 \%$ predictive interval of individual values (- - ) are shown in figures. (a) $y=-0.209 x+18.4(r=-0.88)$ or $\log$ $y=-0.00811 \times+1.29(r=-0.91),(b)$

$y=-71.09 x+6147(r=-0.88)$ or $\log$

$y=-0.0084 x+3.82(r=-0.91),(c)$

$y=-34.788 x+2898(r=-0.85)$ or $\log$

$y=-0.0091 \times+3.49(r=-0.88)$.
Table 5 Relations among P5N activities expressed in three types of unit

\begin{tabular}{llll}
\hline$x$ & $y$ & Regression equation & $r$ \\
\hline$\mu$ mole/h/l RBC & $\mu$ mole/h/g Hb & $\mathrm{y}=0.00295 \times+0.339$ & 0.99 \\
$\mu$ mole/h/l blood & $\mu$ mole/h/g Hb & $\mathrm{y}=0.00569 \times+1.708$ & 0.98 \\
$\mu \mathrm{mole} / \mathrm{h} / \mathrm{l}$ blood & $\mu \mathrm{mole} / \mathrm{h} / \mathrm{l} \mathrm{RBC}$ & $\mathrm{y}=1.929 \times+468$ & 0.98 \\
\hline
\end{tabular}

Samples used were the same in fig $4(n=83)$.

Table 6 Precision of the simplified method

\begin{tabular}{|c|c|c|c|c|}
\hline \multirow[b]{2}{*}{ Sample } & \multicolumn{2}{|l|}{ Within assay } & \multicolumn{2}{|l|}{ Between assay } \\
\hline & $\begin{array}{l}\text { Mean } \pm S D \\
(\mu \text { mole } / h / g ~ H b)\end{array}$ & $\begin{array}{l}C V \\
(\%)\end{array}$ & $\begin{array}{l}\text { Mean } \pm S D \\
(\mu \text { mole } / \mathrm{h} / \mathrm{g} \mathrm{Hb})\end{array}$ & $\begin{array}{l}C V \\
(\%)\end{array}$ \\
\hline $\begin{array}{l}\text { Normal subject } \\
\text { Lead worker }\end{array}$ & $\begin{array}{r}16 \cdot 0 \pm 0.35 \\
6 \cdot 2 \pm 0.29\end{array}$ & $\begin{array}{l}2 \cdot 1 \\
4 \cdot 7\end{array}$ & $\begin{array}{r}15.2 \pm 0.83 \\
6.4 \pm 0.50\end{array}$ & $\begin{array}{l}5 \cdot 5 \\
7 \cdot 8\end{array}$ \\
\hline
\end{tabular}

$\mathrm{n}=8$.

\section{Discussion}

Con $\mathrm{A}$ is a jack bean lectin that binds to $\alpha$-D-mannose and related saccharide residues. Reversible inhibition of $5 \mathrm{~N}$ by Con $\mathrm{A}$ is thought to result from a direct interaction of Con $A$ to saccharide residues on the glycoprotein enzyme molecules. ${ }^{-10}$ Zygowicz et al reported that Con A was a useful reagent in clinical chemistry for differentiating enzymic hydrolysis of $5^{\prime}$-AMP by $5-\mathrm{N}$ from that by alkaline phosphatase in serum, since Con A does not inhibit non-specific hydrolysis of 5'-AMP (adenosine 5'-monophosphate) by alkaline phosphatase. ${ }^{10}$ Although hydrolysis of AMP by erythrocyte $5 \mathrm{~N}$ was reported to be partially inhibited by Con $A,{ }^{10}$ we found that erythrocyte P5N was not affected by the reagent (table 2). When whole blood was used as the enzyme source in P5N assay, substrate UMP was hydrolysed not only by erythrocyte $\mathrm{P} 5 \mathrm{~N}$ but also by plasma $5 \mathrm{~N}$ under neutral conditions. $5 \mathrm{~N}$ activity was almost inhibited by Con $\mathrm{A}$ in amounts exceeding $0.5 \mathrm{mg}$ (fig 1). The sample used in fig 1 showed the highest $5 \mathrm{~N}$ activity among those we experienced in the present study. Therefore $1 \mathrm{mg}$ of Con $A$ was selected to be sufficient to inhibit $5 \mathrm{~N}$ in the assay of P5N activity using whole blood. Using the present method with whole blood and Con A we obtained data comparable with those obtained by the method reported previously in which isolated $\mathrm{RBC}$ were used as the enzyme source. ${ }^{6}$

Serum $5 \mathrm{~N}$ was known to have greater resistance to inactivation by EDTA compared with non-specific alkaline phosphatase. ${ }^{13}$ We found, however, that UMP-hydrolysis by plasma from heparinised blood was suppressed by EDTA treatment in neutral conditions (table 1).

All of the methods reported so far require washed 
$\mathrm{RBC}$ as the enzyme source. Washing erythrocytes is one of the most time consuming steps for assaying P5N activity so the main purpose of the present study was to eliminate the step of $\mathrm{RBC}$ isolation. We successfully determined P5N activity in whole blood without washing erythrocyte, inhibiting the plasma activity for UMP hydrolysis by Con A. P5N activity with the present method with whole blood was comparable with that with washed RBC and correlated well with blood lead concentrations. In the method with whole blood $\mathrm{Hb}$ determination may also be omitted and the activity expressed as $\mu \mathrm{mole} / \mathrm{h} / \mathrm{l}$ blood or $\mu \mathrm{mole} / \mathrm{h} / 1 \mathrm{RBC}$ rather than $\mu \mathrm{mole} / \mathrm{h} / \mathrm{g} \mathrm{Hb}$. The correlation between $\mathrm{Pb}-\mathrm{B}$ and $\log \mathrm{P} 5 \mathrm{~N}$ in $\mu$ mole/ $\mathrm{h} / \mathrm{l}$ blood is slightly lower than that between $\mathrm{Pb}-\mathrm{B}$ and $\log$ P5N in other units because the activity in $\mu$ mole $/ \mathrm{h} / 1$ blood is not corrected to the red cell volume. The activity may be determined even when the blood is partly haemolysed during storage at $4^{\circ} \mathrm{C}$, this has little effect on the activity, ${ }^{614}$ and is expressed as $\mu$ mole/ $/ \mathrm{h} / 1$ blood. Thus the present method eliminates not only isolation of $\mathrm{RBC}$ but also $\mathrm{Hb}$ determination, and is so simple that it may be used for the mass screening of lead exposure.

In a previous paper we showed that the P5N activity in Japanese subjects ${ }^{6}$ was almost twice that in American and European subjects. ${ }^{12415-17}$ Sato et al explained the higher activity in Japanese subjects as due to the lower $\mathrm{Pb}-\mathrm{B}$ concentrations. ${ }^{18}$ In the present study the reference value for P5N activity determined in the control groups was 16.2 \pm 2.5 (arithmetic mean $\pm \mathrm{SD}$ ) but the $\mathrm{Pb}-\mathrm{B}$ values were not determined. These data are similar to those reported by Sato et al,${ }^{18}$ taking into account that the substrate used in our method is UMP. By contrast, Cook et al recently reported normal values \pm SD for P5N activity as $12.0 \pm 0.71(n=14)$, using an HPLC method with UMP as the substrate. ${ }^{19}$ The mean $\mathrm{Pb}$ $\mathrm{B} \pm \mathrm{SD}$ in their control group was $0.37 \pm 0.02 \mu \mathrm{M}$ $(7.6 \pm 4.0 \mu \mathrm{g} / 100 \mathrm{~g})$ which was not so high and similar to that of Japanese subjects. ${ }^{18}$ The normal value for P5N activity by Cook et al $^{19}$ is similar to those reported by American and European investigators ${ }^{12415-17}$ but somewhat lower than those reported here or by Sato et $a l .^{18} \mathrm{It}$ seems that the difference in P5N activity is not only due to the different concentrations of $\mathrm{Pb}-\mathrm{B}$ but also to other factors, including genetic differences.

\section{References}

1 Valentine WN, Fink K, Paglia DE, Harris SR, Adams WS. Hereditary hemolytic anemia with human erythrocyte pyrimidine 5 -nucleotidase deficiency. $J$ Clin Invest 1974;54:866-79.

2 Paglia DE, Valentine WN, Dahlgren JG. Effect of low-level lead exposure on pyrimidine 5 -nucleotidase and other erythrocyte enzymes. Possible role of pyrimidine 5 -nucleotidase in the pathogenesis of lead-induced anemia. $J$ Clin Invest 1975;56:1164-9.

3 Valentine WN, Paglia DE, Fink K, Madokoro G. Lead poisoning. Association with hemolytic anemia, basophilic stippling, erythrocyte pyrimidine 5 '-nucleotidase deficiency, and intraerythrocytic accumulation of pyrimidines. $J$ Clin Invest 1976;58:926-32.

4 Paglia DE, Valentine WN, Fink K. Lead poisoning. Further observations on erythrocyte pyrimidine nucleotidase deficiency and intracellular accumulation of pyrimidine nucleotides. J Clin Invest 1977;60:1362-6.

5 Sakai T, Yanagihara S, Ushio K. Determination of 5'-nucleotidase activity in human erythrocytes and plasma using highperformance liquid chromatography. J Chromatogr 1982; 239:717-21.

6 Sakai T, Ushio K. A simplified method for determining erythrocyte pyrimidine 5 -nucleotidase (P5N) activity by HPLC and its value in monitoring lead exposure. $\mathrm{Br} J$ Ind Med 1986;43:839-44.

7 Dixon TF, Purdom M. Serum 5-nucleotidase. J Clin Pathol 1954;7:341-3.

8 Belfield A, Goldberg DM. Application of a continuous spectrophotometric assay for 5 ' nucleotidase activity in normal subjects and patients with liver and bone disease. Clin Chem 1969;15:931-9.

9 Stefanovic V, Mandel P, Rosenberg A. Concanavalin A inhibition of ecto-5'-nucleotidase of intact cultured C6 glioma cells. J Biol Chem 1975;250:7081-3.

10 Zygowicz ER, Sunderman FW, Horak E, Dooley JF. Inhibition by concanavalin $A$ as the basis for specific assay of serum 5'nucleotidase activity. Clin Chem 1977;23:2311-23.

11 Belfield A, Ellis G, Goldberg DM. A specific colorimetric 5'nucleotidase assay utilising the Berthelot reaction. Clin Chem 1970;16:396-401.

12 Ushio K, Sakai T, Yanagihara S, Watanabe H. Properties of ALA-D ( $\delta$-aminolevulinic acid dehydratase) and the evaluation of lead exposure using heat activation. Japanese Journal of Industrial Health 1975;17:475-82.

13 Young I. Serum 5-nucleotidase: characterisation and evaluation in disease states. Ann NY Acad Sci 1968;75:357-62.

14 Torrance J, West $C$, Beutler $E$. A simple rapid radiometric assay for pyrimidine-5'-nucleotidase. J Lab Clin Med 1977;90:563-8.

15 Ben-Bassat I, Brok-Simoni F, Kende G, Holtzmann F, Ramot B. A family with red cell pyrimidine 5 -nucleotidase deficiency. Blood 1976;47:919-22.

16 Buc H-A, Kaplan J-C. Red cell pyrimidine 5'-nucleotidase and lead poisoning. Clin Chim Acta 1978;87:49-55.

17 Paglia DE, Valentine WN, Brockway R. Identification of thymidine nucleotidase and deoxyribonucleotidase activities among normal isozymes of 5'nucleotidase in human erythrocytes. Proc Natl Acad Sci USA 1984;81:588-92.

18 Sato Y, Sasaki T, Taniguchi N, Saito K. Normal pyrimidine 5'nucleotidase activity level of Japanese subjects and significance as a marker for low concentration of lead in blood. Japanese Journal of Hygiene 1981;36:518-25.

19 Cook LR, Angle CR, Stohs SJ. Erythrocyte arginase, pyrimidine 5 -nucleotidase (P5N), and deoxypyrimidine 5'-nucleotidase (dP5N) as indices of lead exposure. Br J Ind Med 1986;43: 387-90. 